\title{
Applications of Laser in Management of Oral Melanin Pigmentation
}

\author{
Amir Hossein Moaddabi ${ }^{1}$, Ali Moaddabi ${ }^{2}$ and Parisa Soltani ${ }^{3 *}$ \\ ${ }^{1}$ Department of Oral and Maxillofacial Surgery, Isfahan University of Medical Sciences, Iran \\ ${ }^{2}$ Fellowship in Laser Dentistry, Private Practice, Iran \\ ${ }^{3}$ Department of Oral and Maxillofacial Radiology, Shiraz University of Medical Sciences, Iran
}

Submission: January 31, 2017; Published: February 15, 2017

*Corresponding author: Parisa Soltani, Department of Oral and Maxillofacial Radiology, Shiraz University of Medical Sciences, Iran, Tel: +989135599428; Email: parisa.soltani@live.com

\begin{abstract}
Oral melanin pigmentation occurs due to melanin deposition in melanocytes located in basal and suprabasal layers of oral epithelium. This condition can occur due to physiologic or pathologic factors and is considered an esthetic problem. There are several treatment modalities available for oral melanin pigmentation including laser therapy. The present article briefly discusses lasers for management of oral melanin pigmentation.
\end{abstract}

Keywords: Pigmentation; Melanin; Laser

\section{Introduction}

Oral melanin pigmentation occurs due to melanin deposition in melanocytes located in basal and suprabasal layers of oral epithelium [1]. Several etiologic factors have been contributed to oral melanin pigmentation, including endocrine disorders [2], medications such as antimalarial drugs [2], Peutz-Jeghers syndrome [2], tobacco use [3], and physiologic pigmentation [4] since the color of the gingiva plays a significant role in overall esthetics, management of oral melanin pigmentation is important. There are several treatment modalities available for oral melanin pigmentation. Both surgical and non-surgical methods are suggested for this purpose [5]. Pharmaceutical agents have shown limited success in treatment of oral melanin pigmentation [6]. Surgical methods include the use of free gingival graft [7], use of acellular dermal matrix allograft [8], gingivectomy [9], de-epithelialization by abrasion with rotary instruments [10], cryosurgery [11], electrosurgery [12] scalpel [13], and laser $[10,14-16]$.

Recurrences may be expected for each treatment modality $[6,15,17-19]$. The recurrence rate and complications vary with regard to treatment technique and duration of follow-up [14]. Lasers have been introduced to dentistry for more than three decades [20]. Since then different laser modalities have been employed for various purposes, such as caries therapy [21], bleaching [22], wound healing [23], oral and maxillofacial incisions [24], and ablation of pigmented oral mucosa [10,14-
$16,25]$. This mini-review is an attempt to briefly discuss different modalities, mechanism of action, benefits, and drawbacks of lasers for melanin depigmentation of oral mucosa.

\section{Mechanism of Action and Different Laser Modalities}

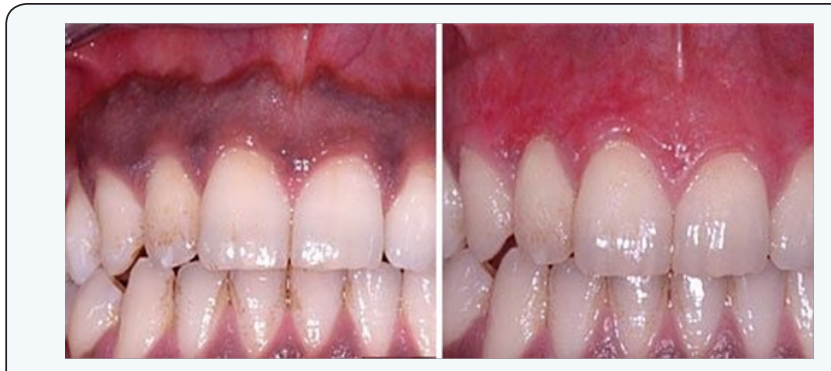

Figure 1: Preoperative and postoperative photograph of removal of gingival pigmentation using diode laser.

Laser treatment of pigmentation is based on selective photothermolysis principle [26]. Laser beam must have a wavelength that is well absorbed by the particular chromophore being removed. Melanin has an absorption spectrum range of $352-1,064 \mathrm{~nm}$ [27]. Also laser energy is transformed into ablation energy, resulting in cellular rupture and vaporization with minimal heating of the surrounding tissue [28]. Different laser techniques have been used for treatment of oral melanin pigmentation, including erbium-doped: yttrium aluminum garnet (Er: YAG) 
laser [10,14-16,25], neodymium-doped: yttrium aluminum garnet (Nd: YAG) laser [29,30], carbon dioxide $\left(\mathrm{CO}_{2}\right)$ laser $[14,17]$, semiconductor diode laser [31,32], chromium and erbium-doped: yttrium scandium gallium garnet (Cr, Er: YSGG) laser [33] (Figure 1). Recommending different modalities requires further studies on the subject because of the paucity of information in this regard.

\section{Advantages and Disadvantages}

Advantages of laser treatment of oral melanin pigmentation include less postoperative discomfort and pain, and lower chairtime compared to scalpel technique (conventional treatment) [34]. Moreover, as laser beam produces a bloodless field for surgery and causes minimal damage to the periosteum and underlying bone, it provides the advantages of easy handling, hemostasis, and decontamination and sterilization effects. Also the treated gingiva and mucosa do not need any dressing [30]. Lasers are considered among the treatments with lower repigmentation rate (1.16\%) [35]. Laser beam destroys basal cells of epithelium and thus reduces the recurrence rate [29]. Other advantages of laser treatment of oral pigmentation include less swelling and scarring [36], and increased patient satisfaction from esthetic outcome [33]. However, this approach needs expensive and sophisticated equipment, which makes the treatment expensive [30]. Also personnel and patient need protection from laser beam. Moreover, some studies suggest that healing of laser wounds is slower than healing of scalpel wounds [37].

\section{Conclusion}

It seems that laser offers a convenient therapy with predictable results for treatment of gingival pigmentation. However, further clinical studies are necessary to determine which laser modalities have the best performance in managing this esthetic problem.

\section{References}

1. Martini F, Timmons, MJ (1995) Human anatomy. Upper Saddle River, Prentice Hall Pub Co., New Jersey, USA.

2. Lenane P, Powell F (2000) Oral pigmentation. J Eur Acad Dermatol Venereol 14(6): 448-465.

3. Sarswathi T, Kumar SN, Kavitha K (2002) Oral melanin pigmentation in smoked and smokeless tobacco users in India. Clinico-pathological study. Indian J Dent Res 14(2): 101-106.

4. Ponnaiyan D, Jegadeesan V, Perumal G, Anusha A (2014) Correlating Skin Color with Gingival Pigmentation Patterns in South Indians-A Cross Sectional Study. Oral Health Dent Manag 13(1): 132-136.

5. Karydis A, Bland P, Shiloah J (2012) Management of Oral Melanin Pigmentation. J Tenn Dent Assoc 92(2): 10-15.

6. Hirschfeld I, Hirschfeld L (1951) Oral pigmentation and a method of removing it. Oral Surg Oral Med Oral Pathol 4(8): 1012-1016.

7. Tamizí M, Taheri M (1996) Treatment of severe physiologic gingival pigmentation with free gingival autograft. Quintessence Int 27(8): 555-558.

8. Novaes AB, Pontes CC, Souza SL, Grisi MF, Taba M (2002) The use of acellular dermal matrix allograft for the elimination of gingival melanin pigmentation: case presentation with 2 years of follow-up. Practical procedures \& aesthetic dentistry: PPAD 14(8): 619-623.
9. Dummett C, Bolden T (1963) Postsurgical clinical repigmentation of the cingivae. Oral Surg Oral Med Oral Pathol 16(3): 353-365.

10. Lee K-M, Lee D-Y, Shin S-I, Kwon Y-H, Chung J-H, et al. (2011) A comparison of different gingival depigmentation techniques: ablation by erbium:yttrium-aluminum-garnet laser and abrasion by rotary instruments. J Periodontal Implant Sci 41(4): 201-207.

11. Arikan F, Gürkan A (2007) Cryosurgical treatment of gingival melanin pigmentation with tetrafluoroethane. Oral Surg Oral Med Oral Pathol Oral Radiol Endod 103(4): 452-457.

12. Bhusari B, Kasat S (2011) Comparison between scalpel technique and electrosurgery for depigmentation: A case series. J Indian Soc Periodontol 15(4): 402-405.

13. Kumara Ajeya E, Avinash J, Rajiv N, Galgali Sushama R (2011) Split mouth gingival depigmentation using blade and diode laser-a case report. Ann Dent Res 1: 91-95.

14. Esen E, Haytac MC, Öz İA, Erdoğan Ö, Karsli ED (2004) Gingival melanin pigmentation and its treatment with the $\mathrm{CO}<\mathrm{sub}>2<$ /sub $>$ laser. Oral Surg Oral Med Oral Pathol Oral Radiol Endod 98(5): 522-527.

15. Rosa DSA, Aranha ACC, de Paula Eduardo C, Aoki A (2007) Esthetic treatment of gingival melanin hyperpigmentation with Er: YAG laser: short-term clinical observations and patient follow-up. J Periodontol 78(10): 2018-2025.

16. Lagdive S, Doshi Y, Marawar P (2009) Management of gingival hyperpigmentation using surgical blade and diode laser therapy: A comparative study. J Oral Laser Applications 9: 41-47.

17. Nakamura Y, Hossain M, Hirayama K, Matsumoto K (1999) A clinical study on the removal of gingival melanin pigmentation with the $\mathrm{CO} 2$ laser. Lasers Surg Med 25(2): 140-147.

18. Bergamaschi O, Kon S, Doine A, Ruben M (1992) Melanin repigmentation after gingivectomy: a 5-year clinical and transmission electron microscopic study in humans. Int J Periodontics Restorative Dent 13(1): 85-92.

19. Hegde R, Padhye A, Sumanth S, Jain AS, Thukral N (2013) Comparison of surgical stripping; erbium-doped:yttrium, aluminum, and garnet laser; and carbon dioxide laser techniques for gingival depigmentation: a clinical and histologic study. J Periodontol 84(6): 738-748.

20. Dederich DN, Bushick RD, ADA Council on Scientific Affairs and Division of Science; Journal of the American Dental Association (2004) Lasers in dentistry: separating science from hype. J Am Dent Assoc 135: 204-212.

21. Keller U, Hibst R, Geurtsen W, Schilke R, Heidemann D, et al. (1998) Erbium: YAG laser application in caries therapy. Evaluation of patient perception and acceptance. J Dent 26(8): 649-656.

22. Buchalla W, Attin T (2007) External bleaching therapy with activation by heat, light or laser-a systematic review. Dent Mater 23(5): 586-596.

23. Conlan MJ, Rapley JW, Cobb CM (1996) Biostimulation of wound healing by low-energy laser irradiation A review. J Clin Periodontol 23(5): 492-496.

24. Liboon J, Funkhouser W, Terris DJ (1997) A comparison of mucosal incisions made by scalpel, $\mathrm{CO}_{2}$ laser, electrocautery, and constantvoltage electrocautery. Otolaryngol Head Neck Surg 116(3): 379-385.

25. Azzeh MM (2007) Treatment of gingival hyper pigmentation by erbiumdoped: yttrium, aluminum, and garnet laser for esthetic purposes. J Periodontol 78(1): 177-184.

26. Anderson RR, Parrish JA (1983) Selective photothermolysis: precise microsurgery by selective absorption of pulsed radiation. Science 220(4596): 524-527.

27. Anderson RR, Margolis RJ, Watenabe S, Flotte T, Hruza GJ, et al. (1989) Selective Photothermolysis of Cutaneous Pigmentation by Q-switched 
Nd: YAG Laser Pulses at 1064, 532. and 355nm. J Invest Dermatol 93(1): 28-32.

28. Ishikawa I, Aoki A, Takasaki AA (2004) Potential applications of Erbium: YAG laser in periodontics. J Periodontal Res 39(4): 275-285.

29. Tal H, Oegiesser D, Tal M (2003) Gingival depigmentation by erbium: YAG laser: Clinical observations and patient responses. J Periodontol 74(11): 1660-1667.

30. Atsawasuwan P, Greethong K, Nimmanon V (2000) Treatment of gingival hyperpigmentation for esthetic purposes by Nd: YAG laser: Report of 4 cases. J Periodontol 71(2): 315-321.

31. Yousuf A, Hossain M, Nakamura Y, Yamada Y, Kinoshita J, Matsumoto $\mathrm{K}$ (2000) Removal of gingival melanin pigmentation with the semiconductor diode laser: A case report. J Clin Laser Med Surg 18(5): 263-266.

32. Gupta G (2011) Management of gingival hyperpigmentation by semiconductor diode laser. J Cutan Aesthet Surg 4(3): 208-210.
33. Berk G, Atici K, Berk N (2005) Treatment of gingival pigmentation with Er, Cr: YSGG Laser. J Oral Laser Applications 5: 249-253.

34. Ribeiro FV, Cavaller CP, Casarin RC, Casati MZ, Cirano FR, et al. (2014) Esthetic treatment of gingival hyperpigmentation with Nd: YAG laser or scalpel technique: a 6-month RCT of patient and professional assessment. Lasers Med Sci 29(2): 537-544.

35. Lin YH, Tu YK, Lu CT, Chung WC, Huang CF, et al. (2014) Systematic review of treatment modalities for gingival depigmentation: a randomeffects poisson regression analysis. J Esthet Restor Dent 26(3): 162178.

36. Sharon E, Azaz B, Ulmansky M (2000) Vaporization of melanin in oral tissues and skin with a carbon dioxide laser: a canine study. J Oral Maxillofac Surg 58(12): 1387-1393.

37. Ozbayrak S, Dumlu A, Ercalik-Yalcinkaya S (2000) Treatment of melanin-pigmented gingiva and oral mucosa by $\mathrm{CO}_{2}$ laser. Oral Surg Oral Med Oral Pathol Oral Radiol Endod 90(1): 14-15.

\section{Your next submission with Juniper Publishers} will reach you the below assets

- Quality Editorial service

- Swift Peer Review

- Reprints availability

- E-prints Service

- Manuscript Podcast for convenient understanding

- Global attainment for your research

- Manuscript accessibility in different formats

( Pdf, E-pub, Full Text, Audio)

- Unceasing customer service

Track the below URL for one-step submission https://juniperpublishers.com/online-submission.php 